Utoguchi, N. and Audus, K.L. (2000) Carrier-mediated transport of valproic acid in BeWo cells, a human trophoblast cell line. Int. J. Pharm. 195, 115-124. PMID: 10675689. Publisher's official version: <http://dx.doi.org/10.1016/S0378-5173(99)003981>. Open Access version: http://kuscholarworks.ku.edu/dspace/.

[This document contains the author's accepted manuscript. For the publisher's version, see the link in the header of this document.]

Paper citation: Utoguchi, N. and Audus, K.L. (2000) Carrier-mediated transport of valproic acid in BeWo cells, a human trophoblast cell line. Int. J. Pharm. 195, 115-124. PMID: 10675689

Keywords: valproic acid; placenta; trophoblast; BeWo; monocarboxylic acid transporter

Abstract: The biochemical mechanisms mediating the rapid distribution of valproic acid across placenta are not precisely known. We have characterized valproic acid transport by the human trophoblast using the human choriocarcinoma cell line, BeWo. The uptake of $\left[{ }^{14} \mathrm{C}\right]$ valproic acid by BeWo cells was found to be saturable and blocked by pre-exposure to the metabolic inhibitors, sodium azide and 2,4-dinitrophenol. Valproic acid uptake by the BeWo cells was also inhibited by the protonophore, carbonylcyanide p-trifluoromethoxyphenylhydrazone (FCCP) but not anion exhange inhibitor. Selected monocarboxylic acids inhibited the uptake of $\left[{ }^{14} \mathrm{C}\right]$ valproic acid by BeWo cells, whereas dicarboxylic acids did not alter the uptake process. Analysis of Lineweaver-Burk plots of valproic acid uptake in the presence of benzoic acid, a marker for the monocarboxylic acid transporter, revealed a competitive process for uptake. In transcellular transport experiments, the permeation of $\left[{ }^{14} \mathrm{C}\right]$ valproic acid from the apical-to-basal side of the monolayers was signficantly greater than the permeation from basal-to-apical side. Additionally, the permeation of $\left[{ }^{14} \mathrm{C}\right]$ valproic acid from apical-to-basal side was inhibited by monocarboxylic acids and not dicarboxylic acids. The results provide biochemical evidence of a protondependent, saturable, and asymmetric transport system, presumed to be a monocarboxylic acid transporter, for valproic acid in a human trophoblast model.

Text of paper:

\title{
CARRIER-MEDIATED TRANSPORT OF VALPROIC ACID IN BEWO CELLS, A HUMAN TROPHOBLAST CELL LINE
}

\author{
NAOKI UTOGUCHI ${ }^{1}$ AND KENNETH L. AUDUS* \\ Department of Pharmaceutical Chemistry, School of Pharmacy, The University of \\ Kansas, 2095 Constant Avenue, Lawrence, Kansas 66047
}

1 Present address: Showa College of Pharmaceutical Sciences, Machida, Tokyo 194-8543, Japan

*Correspondence to: Kenneth L. Audus Tel: 785-864-4138, Fax: 785-864-5736. Email: audus@ukans.edu 
Utoguchi, N. and Audus, K.L. (2000) Carrier-mediated transport of valproic acid in BeWo cells, a human trophoblast cell line.

Int. J. Pharm. 195, 115-124. PMID: 10675689. Publisher's official version: <http://dx.doi.org/10.1016/S0378-5173(99)00398-

1>. Open Access version: http://kuscholarworks.ku.edu/dspace/.

\section{Introduction}

The antiepileptic drug valproic acid readily crosses the placenta and use of the drug in pregnancy is associated with increased fetal malformation and potential toxicity (Barzago et al., 1996). In many instances, valproic acid accumulates in higher concentrations in the fetal blood (Dickinson et al., 1979; Ishizaki et al., 1981; Nau et al., 1982;1984). The biochemical mechanisms mediating the rapid and disproportionate amount of valproic acid distribution across the placenta are not fully understood. Explanations have included observations that with the progression of pregnancy a pH gradient develops across the placental barrier that influences the distribution of weak acids, including valproic acid, and weak bases across the placenta (Nau and Scott, 1986). Maternal levels of fatty acids also rise in the circulation in pregnancy, displacing protein-bound valproic acid which is then available for transfer across the placental barrier (Nau et al., 1984; Nau, 1986) to a milieu with an increased availability of protein binding in the fetal serum (Froesher et al., 1984). Finally, based on comparisons with more polar metabolites, it has been suggested that valproic acid transfer across the placenta is correlated with lipophilicity which facilitates diffusion across the trophoblast interface (Fowler et al., 1989). Therefore, the transfer of valproic acid across the placenta has been attributed to multiple factors.

Valproic acid has been shown to be a substrate for monocarboxylic acid transporters (MCTs) in the gastrointestinal epithelium (Tsuji et al., 1994; Tamai et al., 1995;1997) and specifically by the MCT1 isoform (Tamai et al., 1995). Along with the considerations of $\mathrm{pH}$, protein binding, and lipophilicity considerations, the existence of carrier mechanisms could play an important role determining the distribution of drugs 
Utoguchi, N. and Audus, K.L. (2000) Carrier-mediated transport of valproic acid in BeWo cells, a human trophoblast cell line.

Int. J. Pharm. 195, 115-124. PMID: 10675689. Publisher's official version: <http://dx.doi.org/10.1016/S0378-5173(99)00398-

1>. Open Access version: http://kuscholarworks.ku.edu/dspace/.

and drugs of abuse across the placental barrier (Ganapathy et al., 1999). The mRNAs for five of at least seven putative MCTs have been recently identified in the human placenta (Price et al., 1998). In the absence of specific inhibitors, the functional significance of individual MCT isoforms in the placenta has not been established. However, past studies with brush border membrane preparations from human trophoblasts (Balkovetz et al., 1988) and with the perfused human placental lobe (Carstensen et al., 1983) have revealed proton-dependent, carrier-mediated lactate transport that is presumed to be due to a MCT. We have also demonstrated an asymmetric, proton-dependent, carrier mediated transport of benzoic acid across BeWo cells (Utoguchi et al., 1999), a trophoblast-like human choriocarcinoma cell line (Liu et al., 1997).

We have hypothesized that valproic acid might also be transported via a MCT contributing to the observed distribution of valproic acid across the placental barrier. Therefore, to implicate or rule out the role of a MCT our objective in this study was to characterize the biochemical properties of valproic acid uptake and transport by the human trophoblast using BeWo cells.

\section{Materials and Methods}

2.1 Materials. $\left[{ }^{14} \mathrm{C}\right]$ Valproic acid $(55 \mathrm{Ci} / \mathrm{mol})$ was obtained from American Radiolabeled Chemicals (St. Louis, MO). Fetal bovine serum (FBS) was from JRH Bioscience (Lenexa, KS). Penicillin-streptomycin as a mixture was from Gibco (Gaithersburg, MD). Translucent polycarbonate filters (13 mm diameter, $0.4 \mu \mathrm{m}$ pore 
Utoguchi, N. and Audus, K.L. (2000) Carrier-mediated transport of valproic acid in BeWo cells, a human trophoblast cell line. Int. J. Pharm. 195, 115-124. PMID: 10675689. Publisher's official version: <http://dx.doi.org/10.1016/S0378-5173(99)003981>. Open Access version: http://kuscholarworks.ku.edu/dspace/.

size) were purchased from Fisher Scientific. All other chemicals were of the purest available analytical grade and purchased from Fisher or Sigma (St. Louis, MO).

2.2 Cell Culture. The BeWo cell line was originally derived from a human choriocarcinoma (Pattillo and Gey, 1968). The BeWo clone (b30) was obtained from Dr. Alan Schwartz (Washington University, St. Louis, MO). The cells were cultured by the methods previously described and generally cells used in this study were from passages 28 to 40 (Liu et al, 1997). Briefly, the cells were cultured in Dulbecco's modified Eagle's medium (DMEM) with $10 \%$ heat-inactivated FBS containing $0.37 \%$ sodium bicarbonate and $1 \%$ antibiotics $(10,000 \mathrm{U} / \mathrm{ml}$ penicillin and $10 \mathrm{mg} / \mathrm{ml}$ streptomycin). The cells were maintained in $175-\mathrm{cm}^{2}$ flasks at $\mathrm{pH} 7.4$ under $5 \% \mathrm{CO}_{2}$ and $95 \%$ humidity at $37^{\circ} \mathrm{C}$. The cells were harvested by exposure to a trypsin-EDTA solution (0.25\% trypsin and $0.02 \%$ EDTA in HBSS) and passed onto 12-well tissue culture plates or polycarbonate membranes coated with rat tail collagen in 100-mm culture dishes. With the seeding density of 10,000 cells $/ \mathrm{cm}^{2}$, the cells formed monolayers between 2 and 3 days.

2.3 Uptake Experiments. The BeWo cells at confluence were washed twice with Hanks' balanced salt solution (HBSS; $136.7 \mathrm{mM} \mathrm{NaCl}, 0.385 \mathrm{mM} \mathrm{Na}_{2} \mathrm{HPO}_{4}, 0.441$ $\mathrm{mM} \mathrm{KH}_{2} \mathrm{PO}_{4}, 0.952 \mathrm{mM} \mathrm{CaCl}_{2}, 5.36 \mathrm{mM} \mathrm{KCl}, 0.812 \mathrm{mM} \mathrm{MgSO}_{4}, 25 \mathrm{mM}$ D-glucose and 10 mM HEPES (2-[4-(2-Hydroxyethyl)-1-piperazinyl]ethanesulfonic acid) for adjustment to $\mathrm{pH} 7.0$ or 7.5 or $10 \mathrm{mM}$ MES (2-morpholinoethanesulfonic acid, monohydrate) for adjustment to $\mathrm{pHs}<6.5$ and then the test solution containing $\left[{ }^{14} \mathrm{C}\right]$ valproic acid $(0.25$ 
Utoguchi, N. and Audus, K.L. (2000) Carrier-mediated transport of valproic acid in BeWo cells, a human trophoblast cell line.

Int. J. Pharm. 195, 115-124. PMID: 10675689. Publisher's official version: <http://dx.doi.org/10.1016/S0378-5173(99)00398-

1>. Open Access version: http://kuscholarworks.ku.edu/dspace/.

$\mu \mathrm{Ci} / \mathrm{ml}, 4.6 \mu \mathrm{M})$ was added. The $\mathrm{pH}$ of the test solution was 6.0 except in the $\mathrm{pH}$ dependent uptake experiment. After $30 \mathrm{~s}$, the test solution was aspirated away and the cells were washed with ice-cold HBSS three times. For quantitation of drug uptake, the cells were suspended in $1.0 \mathrm{~N} \mathrm{NaOH}$ and the suspension was incubated at $37^{\circ} \mathrm{C}$ overnight at which point, a half volume of $2.0 \mathrm{~N} \mathrm{HCl}$ was added. Radioactivity was quantitated using a liquid scintillation counter. Cellular protein was quantified using a protein assay kit (Pierce) with bovine serum albumin as a standard. Additional details of the conditions for each experiment are provided in the Figure legends or Table footnotes.

\subsection{Transport Experiments. A horizontal Side-Bi-Side ${ }^{\mathrm{TM}}$ diffusion apparatus} (Crown Glass) was used to measure the transmonolayer permeability of cells grown on the surface of $0.4 \mu \mathrm{m}$ pored polycarbonate filters, as previously described (Liu et al., 1997). The cells faced the donor chamber as the apical side, and the polycarbonate membrane faced the receiver chamber as the basal side. The water jacket surrounding the donor and the receiver chambers was thermostated at $37^{\circ} \mathrm{C}$. The contents of each chamber were continuously stirred at $600 \mathrm{rpm}$ with magnetic stir bars. When the apicalto-basal transport studies were performed, the $\mathrm{pH}$ of the donor (apical) side was 6.0 and that of receptor (basal) side was 7.4. When the basal-to-apical transport studies were performed, the $\mathrm{pH}$ of the donor (basal) side was 6.0 and that of receptor (apical) side was 7.4. The concentration of added $\left[{ }^{14} \mathrm{C}\right]$ valproic acid was $4.6 \mu \mathrm{M}(0.25 \mu \mathrm{Ci} / \mathrm{ml})$. A 0.2-ml aliquot from the receiver chamber was taken at several time points up to $60 \mathrm{~min}$. 
Utoguchi, N. and Audus, K.L. (2000) Carrier-mediated transport of valproic acid in BeWo cells, a human trophoblast cell line.

Int. J. Pharm. 195, 115-124. PMID: 10675689. Publisher's official version: <http://dx.doi.org/10.1016/S0378-5173(99)00398-

1>. Open Access version: http://kuscholarworks.ku.edu/dspace/.

2.5 Permeability Coefficient Calculations. Apparent permeability coefficients for the BeWo monolayers, $\mathrm{P}_{\mathrm{e}}$, was calculated from the following relationship

$$
1 / P_{t}=1 / P_{e}+1 / P_{m}
$$

where Pt is apparent permeability coefficient for the collagen-coated membrane in the presence of BeWo cell monolayers, and $\mathrm{P}_{\mathrm{m}}$ is the apparent permeability coefficient for collagen-coated polycarbonate membrane alone (Adson et al., 1994).

2.6 Data Analysis. To estimate the values of the kinetic parameters of saturable uptake by BeWo cells, the uptake rate (J) was fitted to the following equation, which consists of both saturable and nonsaturable linear terms, using a nonlinear leastsquares regression analysis program MULTI (Yamaoka et al., 1981):

$$
\mathrm{J}=\mathrm{J}_{\max } \times \mathrm{C}^{\prime} /\left(\mathrm{K}_{\mathrm{t}}+\mathrm{C}\right)+\mathrm{k} \times \mathrm{C} \quad \text { Eq. (2) }
$$

where Jmax is the maximum uptake rate for a carrier-mediated process, $\mathrm{C}$ is the valproic acid concentration, $\mathrm{K}_{\mathrm{t}}$ is the half-saturation concentration (Michaelis constant), and $\mathrm{k}$ is a nonsaturable clearance constant.

2.7 Statistical Analysis. All results were expressed as means \pm standard deviation (SD). Statistical analysis between two groups was performed using Student's t-test, and one-way analysis of variance (ANOVA) was used for single and multiple comparisons. $\mathrm{P}$ values of 0.05 or less were considered to indicate a statistically significant difference.

\section{Results}


Utoguchi, N. and Audus, K.L. (2000) Carrier-mediated transport of valproic acid in BeWo cells, a human trophoblast cell line. Int. J. Pharm. 195, 115-124. PMID: 10675689. Publisher's official version: <http://dx.doi.org/10.1016/S0378-5173(99)003981>. Open Access version: http://kuscholarworks.ku.edu/dspace/.

Time and concentration dependence of valproic acid uptake. $\left[{ }^{14} \mathrm{C}\right]$ Valproic acid rapidly accumulated in BeWo cells with time as illustrated in Figure 1. The uptake was linear initially and reached an equilibrium at about 2 min. Therefore, all further uptake studies were performed at $30 \mathrm{~s}$. Figure 2 shows the relationship between the initial rate of uptake of $\left[{ }^{14} \mathrm{C}\right]$ valproic acid and its concentration in the incubation buffer. The results indicated that the uptake of valproic acid consists of two processes, a saturable process evident at low concentrations likely mediated by a carrier mechanism and an apparent nonsaturable process evident at high concentrations. The uptake processes were analyzed according to Eq. (2). The kinetic parameters calculated for valproic acid uptake were a $J_{\max }$ of $29 \mathrm{nmol} / 30 \mathrm{~s} / \mathrm{mg}$ of protein, a $\mathrm{K}_{\mathrm{t}}$ of $0.20 \mathrm{mM}$, and a $\mathrm{k}$ of $6.9 \mu \mathrm{l} / 30$ $\mathrm{s} / \mathrm{mg}$ of protein. The middle dashed line represents the uptake for the saturable component calculated from the kinetic parameters. The lower dotted line represents the uptake for the nonsaturable component calculated from the kinetic parameters. Over the concentration range examined, the uptake by saturable component is higher than the nonsaturable uptake.

Cellular metabolism and $\mathrm{pH}$ dependence of valproic acid uptake. The effects of metabolic inhibitors on the uptake of $\left[{ }^{14} \mathrm{C}\right]$ valproic acid were studied to determine whether this uptake requires cellular energy expenditure as summarized in Table 1. Both sodium azide (10 mM), a respiratory chain inhibitor, and 2,4-dinitrophenol (1 mM), an uncoupler of oxidative phosphorylation, dramatically inhibited the uptake of $\left[{ }^{14} \mathrm{C}\right]$ valproic acid by the BeWo cells. Figure 3 illustrates the effect of incubation buffer $\mathrm{pH}$ in the range from 5.0 to 7.5 on $\left[{ }^{14} \mathrm{C}\right]$ valproic acid uptake by BeWo cells. The rate of $\left[{ }^{14} \mathrm{C}\right]$ valproic acid uptake decreased with increasing $\mathrm{pH}$ from an acidic to a neutral $\mathrm{pH}$. 
Utoguchi, N. and Audus, K.L. (2000) Carrier-mediated transport of valproic acid in BeWo cells, a human trophoblast cell line. Int. J. Pharm. 195, 115-124. PMID: 10675689. Publisher's official version: <http://dx.doi.org/10.1016/S0378-5173(99)003981>. Open Access version: http://kuscholarworks.ku.edu/dspace/.

Moreover, carbonylcyanide p-trifluoromethoxyphenylhydrazone (FCCP; $50 \mu \mathrm{M})$, a protonophore, significantly inhibited the uptake (Table 1), whereas 4,4'-

diisothiocyanostilbene-2,2'-disulfonic acid (DIDS; $0.1 \mathrm{mM}$ ), an anion-exchange inhibitor, had no inhibitory effect. These studies were carried out with concentrations of inhibitors shown to be effective in other cell systems to identify the respective protongradient and anion-exchange mechanisms (Tsuji et al., 1994). These findings suggested that valproic acid uptake by BeWo cells is dependent on cellular energy expenditure and a proton gradient.

Specificity of the valproic acid uptake mechanism. To investigate the specificity of the carrier process involved in $\left[{ }^{14} \mathrm{C}\right]$ valproic acid uptake by BeWo cells, we studied the effects of various mono- and dicarboxylic acids on this uptake. Results are presented in Table 2. Each monocarboxylic acid tested significantly inhibited the uptake of $\left[{ }^{14} \mathrm{C}\right]$ valproic acid, whereas none of the dicarboxylic acids were effective inhibitors. These results imply that the carrier that mediates valproic acid uptake by BeWo cells is a nonspecific monocarboxylic acid carrier.

To characterize the competitive nature of the mechanism mediating uptake of valproic acid, we analyzed the inhibitory effect kinetically. Figure 4A shows a Lineweaver-Burk plot for the uptake of $\left[{ }^{14} \mathrm{C}\right]$ benzoic acid by BeWo cells in the absence or presence of $2 \mathrm{mM}$ valproic acid. Valproic acid competitively inhibited the uptake of benzoic acid by the BeWo cells. Figure 4B shows a Lineweaver-Burk plot for the uptake of $\left[{ }^{14} \mathrm{C}\right]$ valproic acid by BeWo cells in the absence or presence of $2 \mathrm{mM}$ benzoic acid. Benzoic acid competitively inhibited the uptake of valproic acid by the BeWo cells. The inhibition constant for valproic acid was $1.0 \mathrm{mM}$ and the inhibition constant of 
Utoguchi, N. and Audus, K.L. (2000) Carrier-mediated transport of valproic acid in BeWo cells, a human trophoblast cell line.

Int. J. Pharm. 195, 115-124. PMID: 10675689. Publisher's official version: <http://dx.doi.org/10.1016/S0378-5173(99)00398-

1>. Open Access version: http://kuscholarworks.ku.edu/dspace/.

benzoic acid was $0.8 \mathrm{mM}$ and in good agreement with the BeWo cell uptake constant determined for valproic acid from data in Figure 2.

Transmonolayer Transport. The passage of $\left[{ }^{14} \mathrm{C}\right]$ valproic acid across the BeWo monolayer was found to be asymmetric, with the permeability coefficient greater in the apical-to-basal direction than that in the basal-to-apical direction, as shown in Figure 5. The passage of $\left[{ }^{14} \mathrm{C}\right]$ valproic acid across the BeWo monolayers from apical to basal side was not inhibited by a representative dicarboxylic acid (glutaric acid) but was inhibited by an excess amount of unlabeled valproic acid and other representative monocarboxylic acids (benzoic acid and acetic acid) as shown in Figure 6. These findings for transmonolayer valproic acid were consistent with the apical uptake mechanism.

\section{Discussion}

We have characterized the BeWo cell line as an in vitro system to investigate some of the transport and metabolism properties of the human trophoblast (Liu et al., 1997). The BeWo cell line is particularly attractive for these studies because it is stable, relatively easy to maintain by passage, and grows to a confluent monolayer in relatively short period of time. More importantly, the BeWo cell displays morphological properties and biochemical marker enzymes common to normal trophoblasts (Pattillo and Gey, 1968; Liu et al., 1997; Kenagy et al., 1998) and have been shown applicable to the characterization of asymmetric transcellular transport of serotonin and monoamine uptake (Prasad et al., 1996), asymmetric amino acid transport (Furesz et al., 1993; Moe 
Utoguchi, N. and Audus, K.L. (2000) Carrier-mediated transport of valproic acid in BeWo cells, a human trophoblast cell line. Int. J. Pharm. 195, 115-124. PMID: 10675689. Publisher's official version: <http://dx.doi.org/10.1016/S0378-5173(99)003981>. Open Access version: http://kuscholarworks.ku.edu/dspace/.

et al., 1994; Way et al., 1998), asymmetric transferrin transport (Van der Ende et al., 1990; Cerneus et al., 1993), asymmetric fatty acid transport (Liu et al., 1997), choline uptake (Eaton and Sooranna, 1998a), glucose modulation of arginine transport (Eaton and Sooranna, 1998b), and asymmetric IgG transport (Ellinger et al., 1999). Recently, we have shown an asymmetric, proton-dependent transport of representative monocarboxylic acids, benzoic acid and acetic acid, in the BeWo cells (Utoguchi et al., 1999).

In this study, we have been able to establish the putative role of a MCT in carriermediated transport of valproic acid in the trophoblast using the BeWo cell line. Valproic acid uptake (or transport) by BeWo cells was saturable at higher concentrations and strongly inhibited by metabolic inhibitors, properties suggestive of an energy dependent carrier mediated process. Although valproic acid uptake by BeWo cells was not inhibited in a Na+-depleted buffer, prepared by substituting choline chloride for $\mathrm{NaCl}$ and $\mathrm{NaH}_{2} \mathrm{PO}_{4}$ (data not shown), valproic acid uptake was $\mathrm{pH}$ dependent and the protonophore FCCP inhibited the uptake of valproic acid. These results strongly suggest that valproic acid uptake was proton-gradient-dependent. In addition, both valproic acid uptake and transport were significantly inhibited by representative monocarboxylic acids. Kinetic analysis revealed a competitive inhibition with a typical MCT substrate, benzoic acid (Tsuji et al., 1994; Tamai et al., 1995;1997). Finally, the transport of valproic acid was asymmetric, favoring predominant transport in the apical to basolateral direction which corresponds to maternal to fetal distribution of the drug. Collectively, the transport properties of valproic acid were consistent with previous reports on MCT activity in intestinal epithelium (Tsuji et al., 1994; Tamai et al., 
Utoguchi, N. and Audus, K.L. (2000) Carrier-mediated transport of valproic acid in BeWo cells, a human trophoblast cell line. Int. J. Pharm. 195, 115-124. PMID: 10675689. Publisher's official version: <http://dx.doi.org/10.1016/S0378-5173(99)003981>. Open Access version: http://kuscholarworks.ku.edu/dspace/.

1995;1997), the behavior of lactate transport in trophoblast brush border membrane preparations (Balkovetz et al., 1988), and with our earlier work on benzoic acid uptake and transport by BeWo cells (Utoguchi et al., 1999). Therefore, we propose that valproic acid is transported across the human trophoblast by an apparent MCT and this mechanism likely plays a key role in facilitating the rapid and significant distribution of the unbound drug into the fetal compartment.

From previous literature, we noted that there were at least three factors considered important in explaining valproic acid's rapid transfer across the placenta and accumulation in the fetal compartment: the $\mathrm{pH}$ gradient, protein binding, and lipophilicity. Our findings are not inconsistent with the role of these factors. For instance, with the proton-dependent transport by an apparent MCT here is consistent with the observed $\mathrm{pH}$-dependence of valproic acid transfer across the placenta (Nau and Scott, 1986). Similarly, protein binding remains important. Valproic acid is greater than $90 \%$ protein bound, however, the fraction bound decreases with advancing time in pregnancy. It is only the non-protein bound valproic acid that is available for transfer across the placenta (Fowler et al., 1989). To assess free valproic acid transport in an albumin-depleted condition, our studies were performed in the absence of serum. Although not included here, one could consider a series of experiments where serum levels on both sides of the BeWo monolayers are manipulated to approximate protein gradients present across the placenta. We have shown in other studies that serum albumin does substantially reduce the transport of highly bound fatty acids across BeWo monolayers (Liu et al., 1997; Shi et al., 1997). Lastly, concerning the role of lipophilicity, valproic acid can be metabolized to a number of more hydrophilic 
Utoguchi, N. and Audus, K.L. (2000) Carrier-mediated transport of valproic acid in BeWo cells, a human trophoblast cell line. Int. J. Pharm. 195, 115-124. PMID: 10675689. Publisher's official version: <http://dx.doi.org/10.1016/S0378-5173(99)003981>. Open Access version: http://kuscholarworks.ku.edu/dspace/.

metabolites by the liver. Some of the representative valproic acid metabolites are glucuronide conjugates which have a very poor ability to permeate across the placenta. Because it was more lipophilic, valproic acid was proposed to cross the placenta more rapidly than the glucuronide metabolites (Fowler et al., 1989). Considering the possible role of a MCT shown here, an alternative explanation might be the lack of affinity of the valproic acid-glucuronide conjugates for the carrier mechanism. We should note that in the perfused human placental lobe studies (Fowler et al., 1989), recirculating valproic acid is not metabolized for up to six hours. Therefore, in our simpler and shorter timed studies with trophoblasts, the formation of valproic acid metabolites was considered unlikely and would not interfere in the transport studies.

MCT1 appears to be the predominant isoform in tissues such as the intestine and has been shown to provide a mechanism for valproic acid transport (Tsuji et al., 1994; Tamai et al., 1995;1997). By contrast, valproic acid uptake in the brain is believed to be mediated by a medium-chain fatty acid carrier (Adkison and Shen, 1996) and not a MCT. While BeWo cells do possess fatty acid carriers (Liu et al., 1997; Campbell et al., 1997), our data here clearly demonstrated that valproic acid transport can be strongly and competitively inhibited by monocarboxylic acids just as observed in the intestinal epithelium (Tamai et al., 1995). It is possible that valproic acid can be transported differently depending on the tissue location or more likely, be transported by multiple carrier mechanisms at the placental barrier.

Monocarboxylic acids are transported out of muscle and into liver (the so-called Cori cycle) by proton-coupled MCTs. The Cori cycle is a well-known natural physiological process (Garcia et al., 1995). The physiological role of a MCT in the 
Utoguchi, N. and Audus, K.L. (2000) Carrier-mediated transport of valproic acid in BeWo cells, a human trophoblast cell line. Int. J. Pharm. 195, 115-124. PMID: 10675689. Publisher's official version: <http://dx.doi.org/10.1016/S0378-5173(99)003981>. Open Access version: http://kuscholarworks.ku.edu/dspace/.

trophoblast is believed to be one of controlling the distribution of monocarboxylic acid metabolites across the placenta (Carstensen et al., 1983; Balkovetz et al. 1988). Pharmacologically, a placental MCT may be implicated in facilitating monocarboxylic acid drugs (e.g., valproic acid, ibuprofen, salicylate) transfer between the maternal and fetal compartments. This would be in agreement with the proposed role of MCTs in absorption processes in the intestinal epithelium (Tsuji et al., 1994; Tamai et al., 1995;1997; Ogihara et al., 1996). Since, several MCT isoforms are known to exist in a variety of cell types (Price et al., 1998), future studies will have to include identification of the specific the MCT type or types associated with the placental barrier and their respective substrate selectivity properties to fully establish their importance in pharmacology.

In summary, a putative MCT was shown to facilitate valproic acid uptake and transport across a human trophoblast monolayer. MCT-mediated transport of valproic acid represents an alternative mechanism that can be implicated in the observed ready distribution of the drug across the placental barrier. 
Utoguchi, N. and Audus, K.L. (2000) Carrier-mediated transport of valproic acid in BeWo cells, a human trophoblast cell line. Int. J. Pharm. 195, 115-124. PMID: 10675689. Publisher's official version: <http://dx.doi.org/10.1016/S0378-5173(99)003981>. Open Access version: http://kuscholarworks.ku.edu/dspace/.

\section{Acknowledgements}

This work was supported by the National Institute of Drug Abuse (NIDA N01DA4-7405). The authors also acknowledge the Corning Costar Corporation for support of the Cellular and Molecular Biopharmaceutics Handling Laboratory. 
Utoguchi, N. and Audus, K.L. (2000) Carrier-mediated transport of valproic acid in BeWo cells, a human trophoblast cell line.

Int. J. Pharm. 195, 115-124. PMID: 10675689. Publisher's official version: <http://dx.doi.org/10.1016/S0378-5173(99)00398-

1>. Open Access version: http://kuscholarworks.ku.edu/dspace/.

\section{References}

Adkison, K.D.K., Shen, D.D., 1996. Uptake of valproic acid into rat brain is mediated by a medium-chain fatty acid transporter. J. Pharmacol. Exp. Ther., 276, 1189-1200.

Adson, A., Raub, T.J., Burton, P.S., Barsuhn, C.L., Hilgers, A.R., Audus, K.L., Ho, N.F.H., 1994. Quantitative approaches to delineate paracellular diffusion in cultured epithelial cell monolayers. J. Pharm. Sci., 83, 1529-1536.

Balkovetz, D.F., Leibach, F.H., Mahesh, V.B., Ganapathy, V., 1988. A proton gradient is the driving force for uphill transport of lactate in human placental brush-border membrane vesicles. J. Biol. Chem., 263, 13823-13830.

Barzago, N.M., Bortolotti, A., Stellari, F.F., Diomede, L., Algeri, M., Efrati, S., Salmona, M., Bonati, M., 1996. Placental transfer of valproic acid after liposome encapsulation during in vitro human placenta perfusion. J. Pharmacol. Exp. Ther., 277, 79-86.

Campbell, F.M., Cohessy, A.M., Gordon, M.J., Page, K.R., Dutta-Roy, A.K., 1997. Uptake of long chain fatty acids by human placental choriocarcinoma (BeWo) cells: Role of plasma membrane fatty acid binding proteins. J. Lipid Res., 38, 2558-2268.

Carstensen, M.H., Leichtweiss, H.P., Schroder, H., 1983. Lactate carriers in the artificially perfused human term placenta. Placenta, 4, 165-174. 
Utoguchi, N. and Audus, K.L. (2000) Carrier-mediated transport of valproic acid in BeWo cells, a human trophoblast cell line. Int. J. Pharm. 195, 115-124. PMID: 10675689. Publisher's official version: <http://dx.doi.org/10.1016/S0378-5173(99)003981>. Open Access version: http://kuscholarworks.ku.edu/dspace/.

Cerneus, D.P., Strous, G.J., Van der Ende, A., 1993. Bidirectional transcytosis determines the steady state distribution of the transferrin receptor at opposite plasma domaines of BeWo cells. J. Cell Biol., 122, 1223-1230.

Dickinson, R.G., Harland, R.C., Lynn, R.K., Smith, W.B., Gerbe, N., 1979. Transmission of valproic acid (Depakene) across the placenta: Half-life of the drug in mother and baby. J. Pediatr., 94, 832-835.

Eaton, B.M., Sooranna, S.R., 1998a. Regulation of the choline transport system in superfused microcarrier cultures of BeWo cells. Placenta, 19, 663-669.

Eaton, B.M., Sooranna, S.R., 1998b. In vitro modulation of L-arginine transport in trophoblast cells by glucose. Eur. J. Clin. Invest., 28, 1006-1010.

Ellinger, I., Schwab, M., Stefanescu, A., Hunziker, W., Fuchs, R., 1999. IgG transport across trophoblast-derived BeWo cells: A model system to study IgG transport in the placenta. Eur. J. Immunol., 29, 733-744.

Fowler, D.W., Eadie, M.J., Dickinson, R.G., 1989. Transplacental transfer and biotransformation studies of valproic acid and its glucuronide(s) in the perfused human placenta. J. Pharmacol. Exp. Ther., 249. 318-323. 
Utoguchi, N. and Audus, K.L. (2000) Carrier-mediated transport of valproic acid in BeWo cells, a human trophoblast cell line. Int. J. Pharm. 195, 115-124. PMID: 10675689. Publisher's official version: <http://dx.doi.org/10.1016/S0378-5173(99)003981>. Open Access version: http://kuscholarworks.ku.edu/dspace/.

Froescher, W., Gugler, R., Niesen, M., Hoffmann, F., 1984. Protein binding of valproic acid in maternal and umbilical cord serum. Epilepsia, 25, 244-249.

Furesz, T.C., Smith, C.H., Moe, A.J., 1993. ASC system activity is altered by development of cell polarity in trophoblast from human placenta. Am. J. Physiol., 265, C212-C217.

Ganapathy, V., Prasad, P.D., Ganapathy, M.E., Leibach, F.H., 1999. Drugs of abuse and placental transport. Adv. Drug Del. Rev., 38, 99-110.

Garcia, C.K., Brown, M.S., Pathak, R.K., Goldstein, J.L., 1995. cDNA cloning of MCT2, a second monocarboxylate transporter expressed in different cells than MCT1. J. Biol. Chem., 270, 1843-1849.

Getin, I., Marcomi, A.M., Baggiani, A.M., Buscaglia, M., Pardi, G., Fennessey, P.V., Battaglia, F.C., 1995. In vivo placental transport of glycine and leucine in human pregnancies. Pediatr. Res., 37, 571-575.

Hay, W.W. Jr., 1994. Placental transport of nutrients to the fetus. Horm. Res., 42, 215222. 
Utoguchi, N. and Audus, K.L. (2000) Carrier-mediated transport of valproic acid in BeWo cells, a human trophoblast cell line. Int. J. Pharm. 195, 115-124. PMID: 10675689. Publisher's official version: <http://dx.doi.org/10.1016/S0378-5173(99)003981>. Open Access version: http://kuscholarworks.ku.edu/dspace/.

Ishizaki, T., Yokochi, K., Chiba, K., Tabuchi, T., Wagatsuma, T., 1981. Placental transfer of anticonvulsants (phenobarbital, phenytoin, valproic acid) and the elimination from neonates. Pediatr. Pharmacol. (New York), 1, 291-303.

Karl, P.I., Alpy, K.L., Fisher, S.E., 1992. Amino acid transport by the cultured human placental trophoblast: effect of insulin on AIB transport. Am. J. Physiol., 262, C834C839.

Kenagy, J., Liu, F., Soares, M.J., Audus, K.L., 1998. Gestational and smoking effects on peptidase activity in the placenta. Peptides, 19, 1659-1666.

Liu, F., Soares, M., Audus, K.L., 1997. Permeability properties of monolayers of the human trophoblast cell line BeWo. Am. J. Physiol., 273, C1596-C1604.

Moe, A.J., Furesz, T.C., Smith, C.H., 1994. Functional characterization of L-alanine transport in a placental choriocarcinoma cell line (BeWo). Placenta, 15, 797-802.

$\mathrm{Nau}, \mathrm{H} ., 1986$. Species differences in pharmacokinetics and drug teratogenesis. Environ. Health Perspect., 70, 113-129.

Nau, H., Scott, W.J. Jr., 1986. Weak acids may act as teratogens by accumulating in the basic millieu of the early mammalian embryo. Nature, 323, 276-278. 
Utoguchi, N. and Audus, K.L. (2000) Carrier-mediated transport of valproic acid in BeWo cells, a human trophoblast cell line. Int. J. Pharm. 195, 115-124. PMID: 10675689. Publisher's official version: <http://dx.doi.org/10.1016/S0378-5173(99)003981>. Open Access version: http://kuscholarworks.ku.edu/dspace/.

Nau, H., Helge, H., Luck, W. ,1984. Valproic acid in the perinatal period: Decreased maternal serum protein binding results in fetal accumulation and neonatal displacement of the drug and some metabolites. J. Pediatr., 104, 627-634.

Nau, H., Kuhnz, W., Egger, H.J., Rating, D., Helge, H., 1982. Anticonvulsants during pregnancy and lactation. Transplacental, maternal and neonatal pharmacokinetics. Clin. Pharmacokinet., 7, 508-543.

Ogihara, T., Tamai, I., Takanaga, H., Sai, Y., Tsuji, A., 1996. Stereoselective and carrier-mediated transport of monocarboxylic acids across Caco-2 cells. Pharm. Res., $13,1828-1832$.

Pattillo, R.A., Gey, G.O., 1968. The establishment of a cell line of human hormonesynthesizing trophoblast cell in vitro. Cancer Res., 28, 1231-1236.

Prasad, P.D., Hiffmans, B.J., Moe, A.J., Smith, C.H., Leibach, F.H., Ganapathy, V., 1996. Functional expression of the plasma membrane serotonin transporter but not the vesicular monoamine transporter in human placental trophoblasts and choriocarcinoma cells. Placenta, 9, 201-207.

Price, N.T., Jackson, V.N., Halestrap, A.P., 1998. Cloning and sequencing of four new mammalian monocarboxylate transport (MCT) homologues confirms the existence of a transporter family with an ancient past. Biochem. J., 329, 321-328. 
Shi, F., Soares, M.J., Avery, M., Liu, F., Zhang, X., Audus, K.L., 1997. Permeability and metabolic properties of a trophoblast cell line (HRP-1) derived from normal rat placenta. Exp. Cell Res., 234, 147-155.

Tamai, I., Takanaga, H., Maeda, H., Sai, Y., Ogihara, T., Higashida, H., Tsuji, A., 1995. Participation of a proton-contransporter, MCT1, in the intestinal transport of monocarboxylic acids. Biochem. Biophys. Res. Commun., 214, 482-489.

Tamai, I., Takanaga, H., Maeda, H., Yabuuchi, H., Sai, Y., Suzuki, Y., Tsuji, A., 1997. Intestinal brush-border membrane transport of monocarboxylic acids mediated by proton-coupled transport and anion transport mechanisms. J. Pharm. Pharmacol., 49, 108-112.

Tsuji, A., Takanaga, H., Tamai, I., Terasaki, T., 1994. Transcellulara transport of benzoic acid across Caco-2 cells by a pH-dependent and carrier-mediated transport mechanism. Pharm. Res., 11, 30-37.

Utoguchi, N., Magnusson, M., Audus, K.L., 1999. Carrier-mediated transport of monocarboxylic acids in BeWo cell monolayers as a model of the human trophoblast. $\mathrm{J}$. Pharm. Sci., 88, in press. 
Utoguchi, N. and Audus, K.L. (2000) Carrier-mediated transport of valproic acid in BeWo cells, a human trophoblast cell line. Int. J. Pharm. 195, 115-124. PMID: 10675689. Publisher's official version: <http://dx.doi.org/10.1016/S0378-5173(99)003981>. Open Access version: http://kuscholarworks.ku.edu/dspace/.

Van der Ende, A.A., Du Maine, A., Schwartz, A.L., Strous, G.J., 1990. Modulation of transferrin-receptor activity and recycling after induced differentiation of BeWo choriocarcinoma cells. Biochem. J., 270, 451-457.

Way, B.A., Furesz, T.C., Schwarz, J.K., Moe, A.J., Smith, C.K., 1998. Sodiumindependent lysine uptake by the BeWo choriocarcinoma cell line. Placenta, 19, 323328.

Yamaoka, K., Tanigawara, Y., Nakagawa, T., Uno, T., 1981. A pharmacokinetic analysis program (MULTI) for microcomputer. J. Pharmacobio-Dyn., 4, 879-885. 


\section{Figure Legends}

Figure 1. Time-dependent uptake of $\left[{ }^{14} \mathrm{C}\right]$ valproic acid $(4.6 \mu \mathrm{M})$ by BeWo cell monolayers. Each data point represents the mean \pm SD of four experiments.

Figure 2. Concentration-dependent uptake of $\left[{ }^{14} \mathrm{C}\right]$ valproic acid by BeWo cell monolayers. The uptake of $\left[{ }^{14} \mathrm{C}\right]$ valproic acid by BeWo cells was measured at $37^{\circ} \mathrm{C}$ for $30 \mathrm{~s}$ and is represented by the solid line through the data points. The middle dashed line represents the uptake for the saturable component calculated from the kinetic parameters obtained as described in the text. The lower dotted line represents the uptake for the nonsaturable component calculated from the kinetic parameters. Each data point represents the mean $\pm S D$ of four experiments.

Figure 3. The $\mathrm{pH}$ dependence of $\left[{ }^{14} \mathrm{C}\right]$ valproic acid $(4.6 \mu \mathrm{M})$ uptake by BeWo cell monolayers. The uptake of $\left[{ }^{14} \mathrm{C}\right]$ valproic acid by BeWo cells was measured in the presence of the indicated $\mathrm{pH}$ at $37^{\circ} \mathrm{C}$. Each point represents the mean $\pm \mathrm{SD}$ of four experiments.

Figure 4. Lineweaver-Burk plots for the uptake of benzoic acid and valproic acid by BeWo cell monolayers. A: Benzoic acid uptake was measured in the absence $(\bigcirc)$ or presence of $2 \mathrm{mM}$ valproic acid ( $)$. B: Valproic acid uptake was measured in the absence $(\triangle$ ) or presence of $2 \mathrm{mM}$ benzoic acid $(\Delta)$. The vertical bar through each point represents the SD of four experiments. 
Utoguchi, N. and Audus, K.L. (2000) Carrier-mediated transport of valproic acid in BeWo cells, a human trophoblast cell line. Int. J. Pharm. 195, 115-124. PMID: 10675689. Publisher's official version: <http://dx.doi.org/10.1016/S0378-5173(99)003981>. Open Access version: http://kuscholarworks.ku.edu/dspace/.

Figure 5. Permeation of $\left[{ }^{14} \mathrm{C}\right]$ valproic acid across BeWo cell monolayers from apical to basal side $(A$ to $B)$ or from basal to apical side $(B$ to $A)$. Each point represents the mean $\pm S D$ of four experiments. * $p<0.001$ vs $A$ to $B$

Figure 6. Effects of selected mono- and di-carboxylic acids on the permeation of $\left[{ }^{14} \mathrm{C}\right]$ valproic acid across BeWo cell monolayers from apical to basal side. Each carboxylic acid was added to a final concentration of $10 \mathrm{mM}$. Each point represents the mean $\pm \mathrm{SD}$ of four experiments. $\quad * p<0.001$ vs control $\left(\left[{ }^{14} \mathrm{C}\right]\right.$ valproic acid alone $)$. 
Utoguchi, N. and Audus, K.L. (2000) Carrier-mediated transport of valproic acid in BeWo cells, a human trophoblast cell line. Int. J. Pharm. 195, 115-124. PMID: 10675689. Publisher's official version: <http://dx.doi.org/10.1016/S0378-5173(99)003981>. Open Access version: http://kuscholarworks.ku.edu/dspace/.

Figure 1

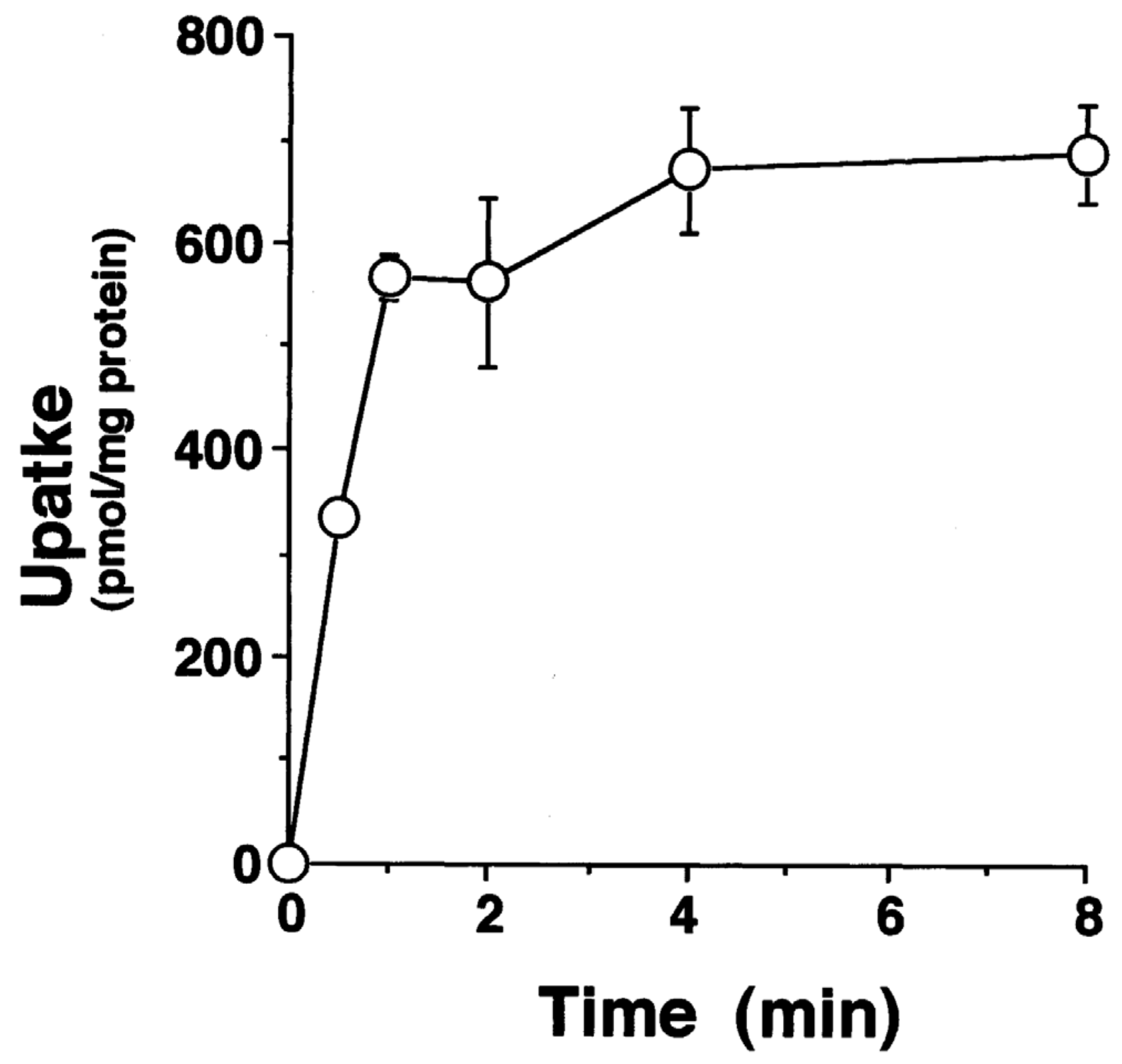


Utoguchi, N. and Audus, K.L. (2000) Carrier-mediated transport of valproic acid in BeWo cells, a human trophoblast cell line. Int. J. Pharm. 195, 115-124. PMID: 10675689. Publisher's official version: <http://dx.doi.org/10.1016/S0378-5173(99)003981>. Open Access version: http://kuscholarworks.ku.edu/dspace/.

Figure 2

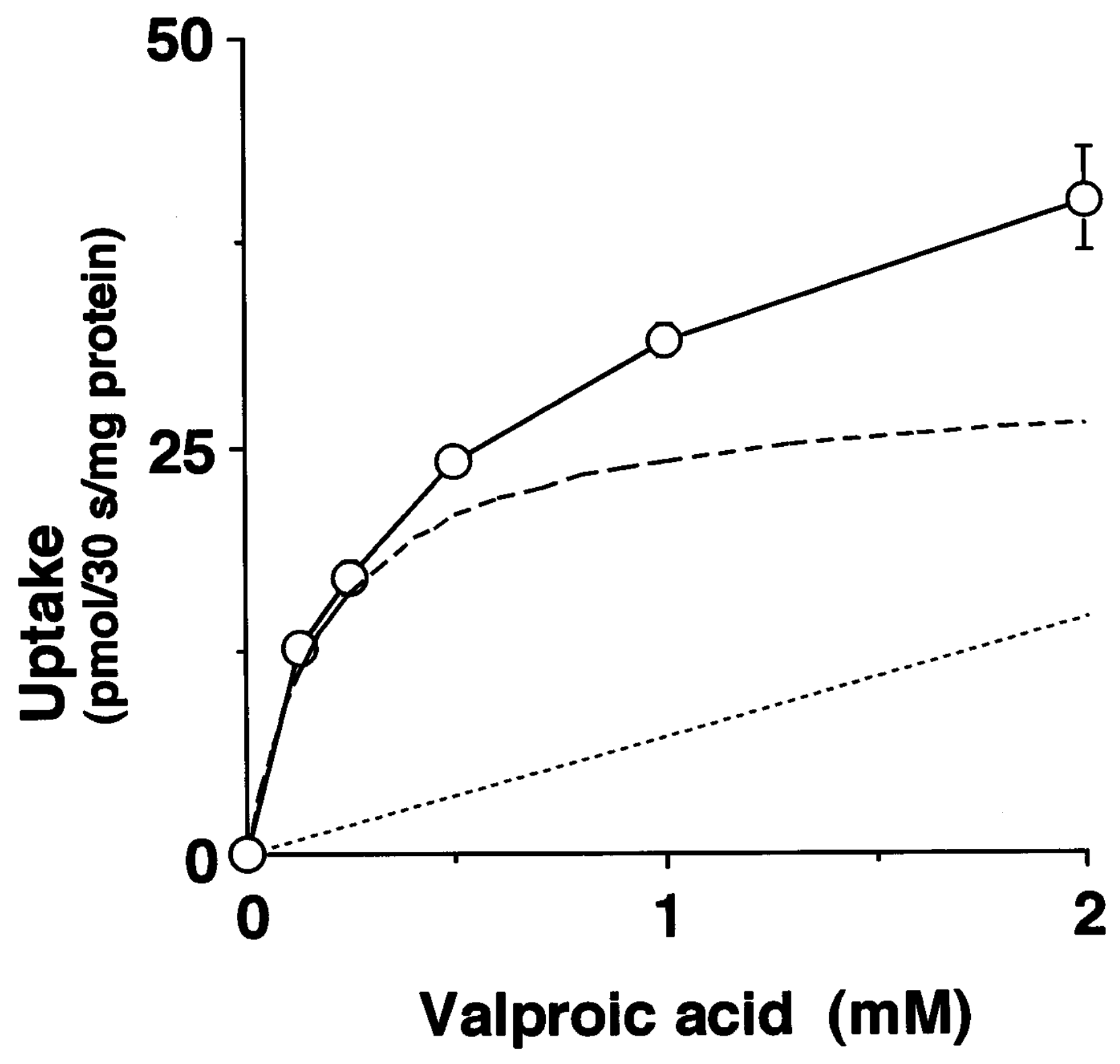


Utoguchi, N. and Audus, K.L. (2000) Carrier-mediated transport of valproic acid in BeWo cells, a human trophoblast cell line. Int. J. Pharm. 195, 115-124. PMID: 10675689. Publisher's official version: <http://dx.doi.org/10.1016/S0378-5173(99)003981>. Open Access version: http://kuscholarworks.ku.edu/dspace/.

Figure 3

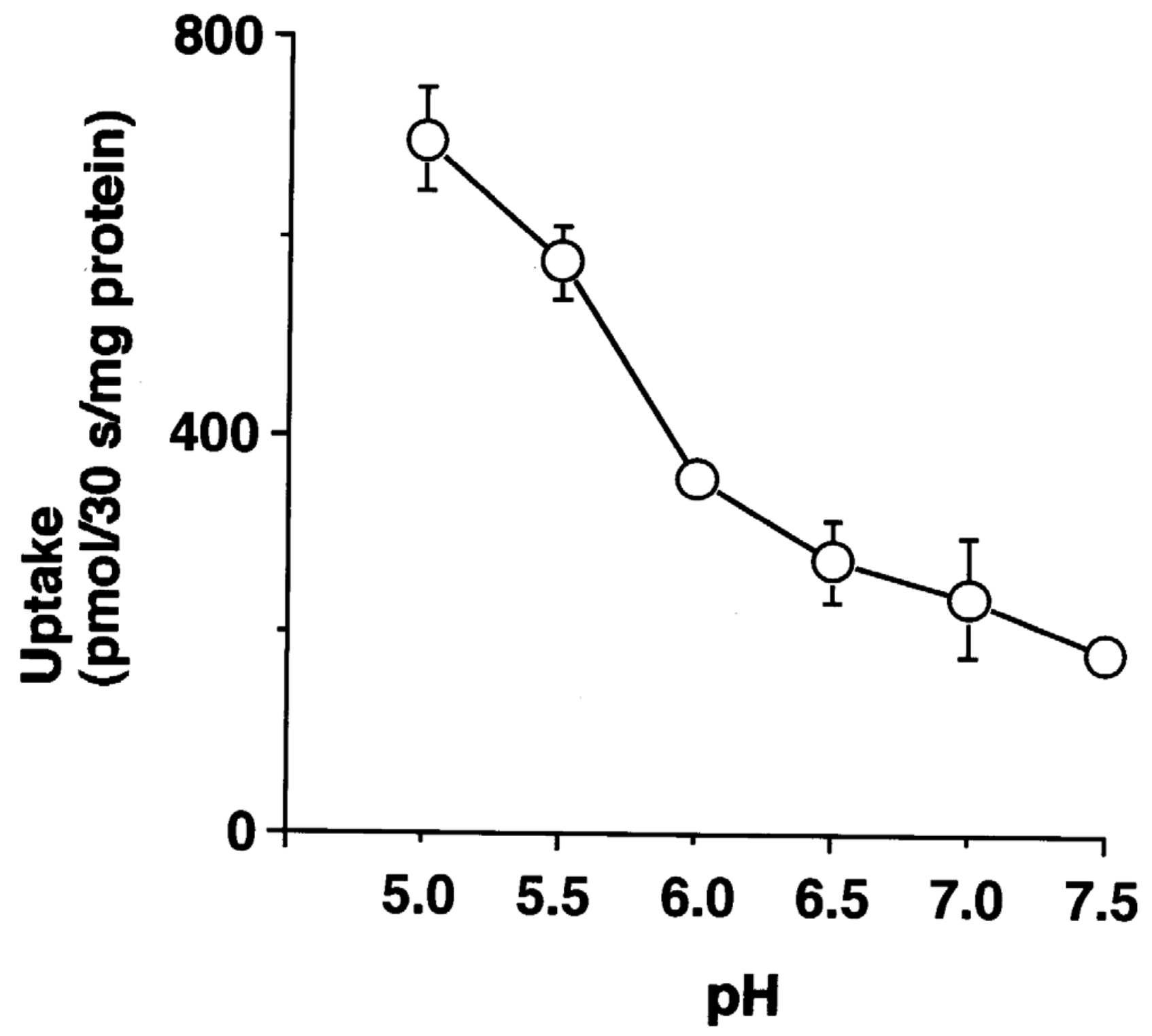


Utoguchi, N. and Audus, K.L. (2000) Carrier-mediated transport of valproic acid in BeWo cells, a human trophoblast cell line. Int. J. Pharm. 195, 115-124. PMID: 10675689. Publisher's official version: <http://dx.doi.org/10.1016/S0378-5173(99)003981>. Open Access version: http://kuscholarworks.ku.edu/dspace/.

Figure 4
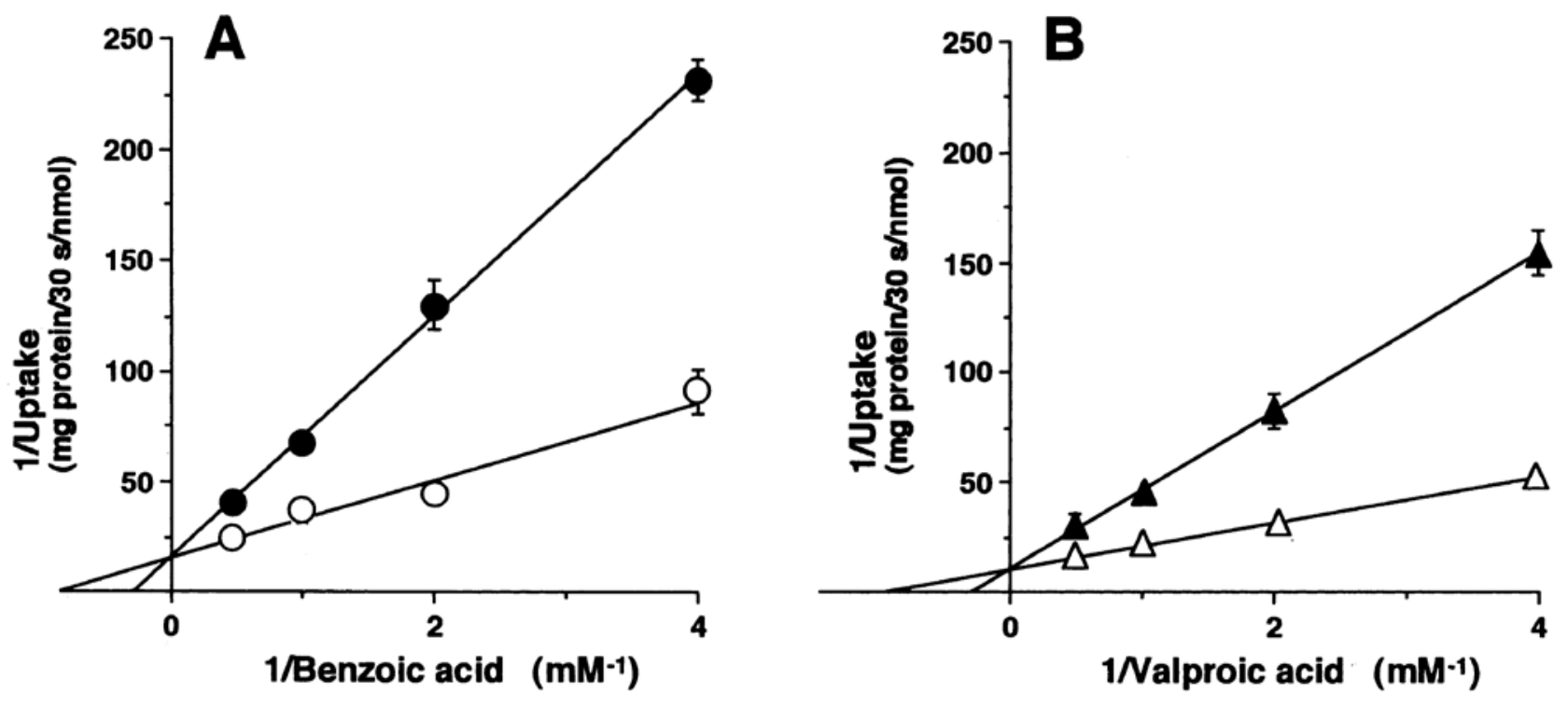
Utoguchi, N. and Audus, K.L. (2000) Carrier-mediated transport of valproic acid in BeWo cells, a human trophoblast cell line. Int. J. Pharm. 195, 115-124. PMID: 10675689. Publisher's official version: <http://dx.doi.org/10.1016/S0378-5173(99)003981>. Open Access version: http://kuscholarworks.ku.edu/dspace/.

Figure 5

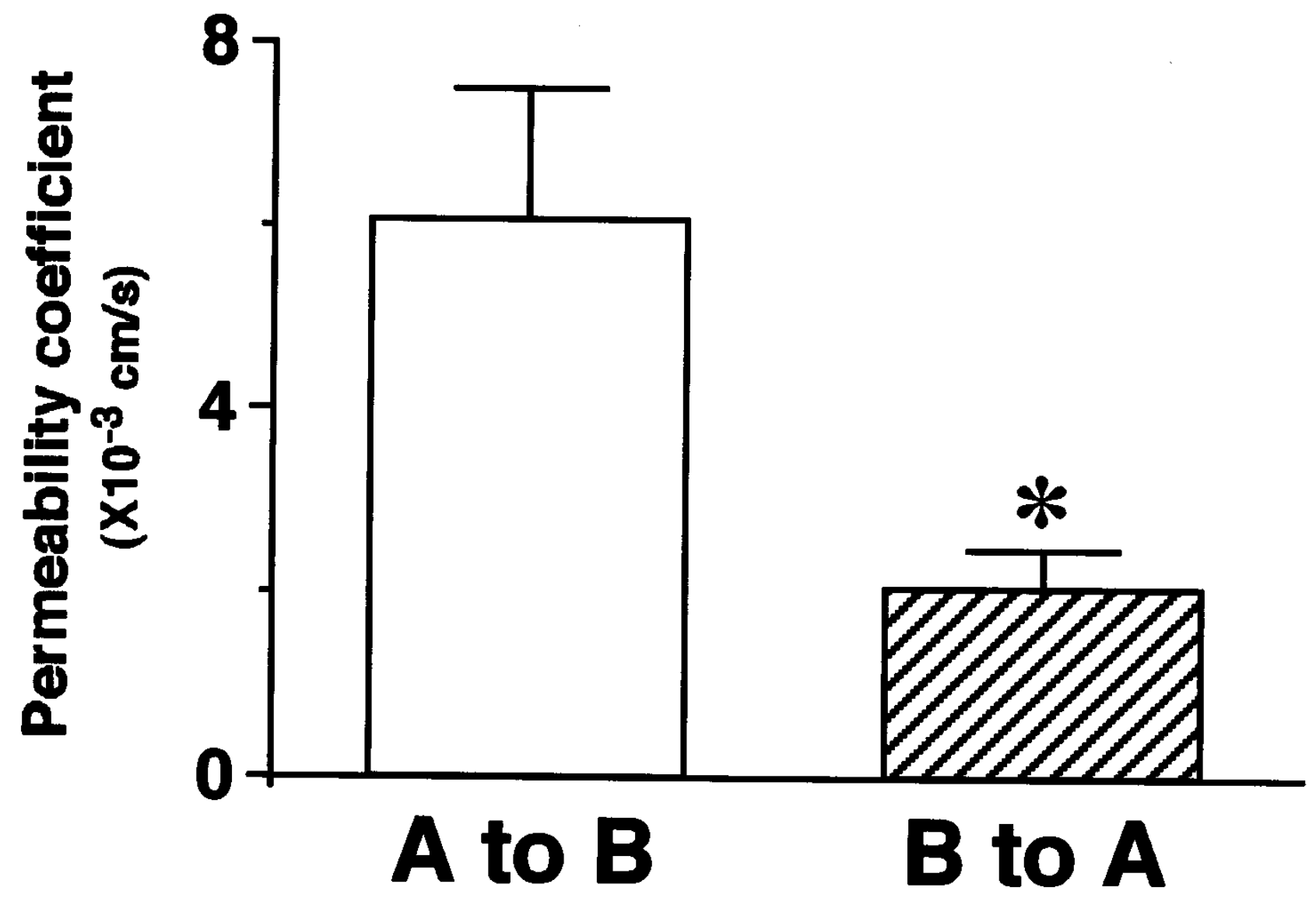


Utoguchi, N. and Audus, K.L. (2000) Carrier-mediated transport of valproic acid in BeWo cells, a human trophoblast cell line. Int. J. Pharm. 195, 115-124. PMID: 10675689. Publisher's official version: <http://dx.doi.org/10.1016/S0378-5173(99)003981>. Open Access version: http://kuscholarworks.ku.edu/dspace/.

Figure 6

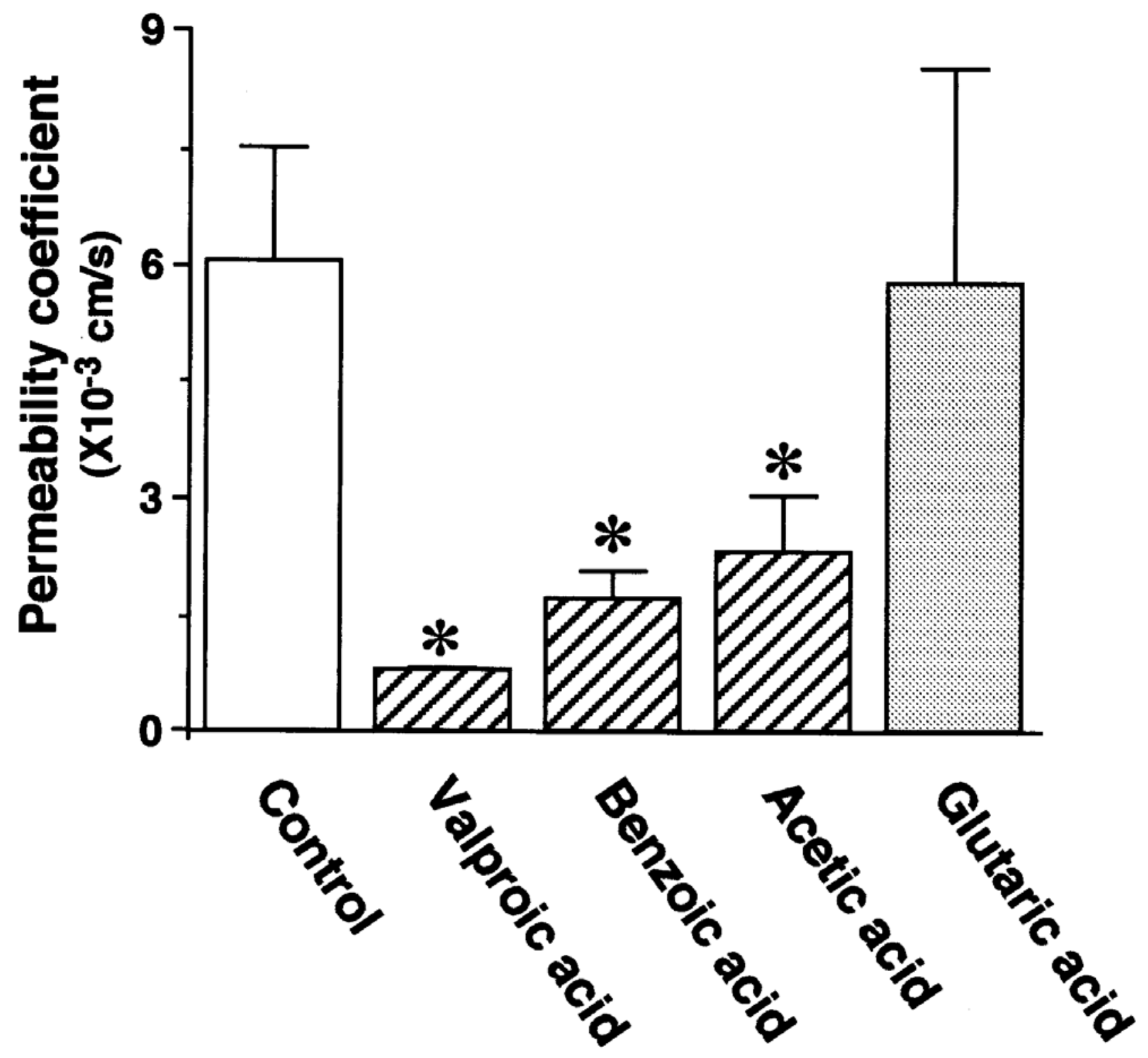

